\title{
The Sarbanes-Oxley Act: A Cost-Benefit Analysis Using The U.S. Banking Industry
}

Philip H. Siegel, Augusta State University, USA

David P. Franz, San Francisco State University, USA

John O'Shaughnessy, San Francisco State University, USA

\begin{abstract}
There are many analyses of the economic effects that regulations, in general, and Sarbanes-Oxley Act, in particular, have had on American business. This analysis looks at the effect that the Sarbanes-Oxley Act has had on the American banking industry. The return on assets and return on equity were obtained from the Federal Reserve Bank for all SEC-registered and nonregistered banks for the period 2000 through 2005. Comparative results indicate that during the period that the Act had been in effect there is a marked negative divergence for SEC-registered banks as opposed to those banks that do not report to the SEC.
\end{abstract}

\section{INTRODUCTION}

overnment regulations can have profound effects on industry. Regulation can be defined as the government directly "prescribing and proscribing what private sector agents can and cannot do, so that their actions do not contradict the 'public interest."' (Chang, 1997) Prescribing or proscribing actions can be both productive and costly for a firm as well as the public. The resulting regulations of the 2002 Sarbanes-Oxley Act (SOX) have been described as being costly to U. S. business. By comparing the returns on assets (ROA) and returns on equity (ROE) of registered (SEC reporting) vs nonregistered (nonSEC reporting) U.S. banks, this study attempts to determine if SOX has had a detrimental effect on registered banks.

\section{The Economic Effect of Regulations}

Benston (1976) discussed the U.S. experience of industry regulation. He noted that once power is granted to a "regulatory agency, they almost never contract and almost always expand, regardless of their demonstrated lack of efficacy for solving problems or propensity to create new problems." This is mirrored by Joshi, Krishnan, and Lave (2001), Meyer (1975), and Peterson (1975) found that higher costs are usually associated with a regulated environment and that sometimes, the regulatory costs are not worth the benefits. This is also suggested in Hahn's (1998) research.

Regulatory policies can have a detrimental economic effect for entire industries as well as the U.S. economy. Analyses of U. S. regulations indicate that they hinder American railroads, insurance industry, and public utilities (Caves, Christensen and Johnson, 1981), (Darby, 2007), (Taggart, 1985), (Pociask and Fuhr, 2007). Regarding the U.S. economy, according to Gray (1987) OSHA and EPA regulations were responsible for over 30 percent of the economic slowdown in the 1970's.

Over-regulation (Harvard Law Review 2003) can become counterproductive. Companies can become routinized in regulatory compliance in such a manner that they are adhering to the letter of the law but not the spirit. Niskanen (2007) theorized that the U.S. capital markets may be dangerously over-regulated. He cites two recent reports: the Committee on Capital Markets Regulation's report documenting the declining U.S. competitiveness and the Schumer-Bloomberg Report which warned that U.S. financial service revenues would fall between $\$ 15$ billion and $\$ 30$ billion a year without a major change in the public policies affecting US capital markets. 


\section{Regulations Concerning Accounting}

Regulations also appear in the form of required accounting disclosure and can produce beneficial effects. A company's credibility can be enhanced by consistent and effective disclosure (Gibbins, Richardson, and Waterhouse, 1990). Increased disclosure benefits firms and the capital markets (Leuz and Verrecchia, 2000), (Dhaliwal, 1979), (Meier-Schatz, 1986).

On the other hand mandatory disclosure can be cumbersome and costly. Research by Admati and Pfleiderer (2000) suggests that the diverse nature of industries make it difficult to design effective universal disclosure. According to Benston (1977) an unaware public pays for government-required accounting disclosure. Sunstein (1999) claims that disclosure of information allows the federal government to control public and private conduct.

\section{Foreign Corrupt Practices Act}

Over the decades accounting regulations have come from various sources. The Securities and Exchange Commission as well as the Internal Revenue Service and Interstate Commerce Commission are examples of regulatory bodies that promulgate accounting regulations. A more recent example occurred during the 1970s. During the Watergate era there were a number of investigations, some of which affected American business. One of the investigations, conducted by the Securities and Exchange Commission (SEC) in 1975, revealed that 19 publiclyheld corporations had made illegal campaign contributions and that these contributions were made from cash accounts that had not been recorded on the corporation's books. (Heldack, 1977) This prompted the SEC to launch an investigation into what were considered "questionable payments." What came out of the investigation was that many U.S. multinational corporations were making hundreds of millions of dollars in "questionable payments" to foreign officials to obtain business.

As a result, the Foreign Corrupt Practices Act (FCPA) was unanimously adopted by Congress in 1977. Bribery of foreign officials to obtain business for the corporation became illegal but the FCPA also included a second provision requiring all publicly-held companies establish an effective system of internal controls. This was in response to revelations that payments to foreign officials were paid with "off-the-books" cash accounts.

Some of the research into the effects on American business by the FCPA indicates that the anti-bribery provision of the Foreign Corrupt Practices Act has cost the U.S. in terms of lost business and competitive advantage. (Koretz 1996), (Beck, Maher, and Tschoegl, 1991), (Kaikati, and Label 1980). On the other hand there are studies that indicate the opposite; that the anti-bribery provision has been beneficial to U. S. business. (Graham, 1984), (Richman 1979)

Regarding the internal control provision, Maher (1981) found that, while some benefits would accrue from the FCPA provision, it has led to costly compliance efforts. For instance, the FCPA affected significantly the internal auditing department budget. One poll indicated during the period 1978 through 1982 internal audit budgets across the U.S. increased approximately 79 percent. (Baird and Michenzi, 1983)

\section{National Commission on Fraudulent Financial Reporting}

During the 1980s there was a number of management frauds perpetrated against investors - (eg. ESM Government Securities and ZZZZ Best). A round of congressional hearings on regulating the accounting profession ensued. As a possible countermeasure by industry a jointly-sponsored commission (American Institute of Certified Public Accountants, Institute of Management Accountants, Institute of Internal Auditors, Financial Executives Institute, and the American Accounting Association) called the National Commission on Fraudulent Financial Reporting (informally called the Treadway Commission) was chaired by James C. Treadway, former commissioner of the Securities and Exchange Commission, made 49 recommendations many of which were direct toward public companies and regulatory agencies. (Committee of Sponsoring Organizations, 1987) While the recommendations are not considered regulations per se, their purpose was to stave off further governmental regulation. 
Among the recommendations were calls for stronger internal controls, more effective corporate internal audit function and better external auditor fraud detection. Some of the research that followed these recommendations placed emphasis in these areas. There were studies and discussions regarding the resulting increased audit fees and internal control costs, that auditors were deterrents to fraud, and that internal auditing could lessen external audit fees (Matsumura and Tucker, 1992), (Copley, Doucet, and Gaver, 1994), (Schneider and Wilner, 1990), (Felix, Gramling, and Maletta, 2001) (CA Magazine, 1994) .

Sarbanes-Oxley Act

In response to the Arthur Andersen, Enron and WorldCom-era debacles, Congress passed "Public Company Accounting Reform and Investor Protection Act" in July 2002. Sponsored by Mike Oxley (R-OH) and Paul Sarbanes (D-MD) the Act has become popularly known as the "Sarbanes-Oxley Act" (Act or SOX). The purpose of the Act is to restore public confidence in both public accounting and publicly-traded securities as well as promote better ethical business practices through greater executive awareness and accountability.

One of the costly aspects to SOX comes from section 404 whereby:

Section 404 of the Act directs the Commission [SEC] to adopt rules requiring each annual report of a company, other than a registered investment company, to contain (1) a statement of management's responsibility for establishing and maintaining an adequate internal control structure and procedures for financial reporting; and (2) management's assessment, as of the end of the company's most recent fiscal year, of the effectiveness of the company's internal control structure and procedures for financial reporting. Section 404 also requires the company's auditor to attest to, and report on management's assessment of the effectiveness of the company's internal controls and procedures for financial reporting in accordance with standards established by the Public Company Accounting Oversight Board (PCAOB). (SEC 2003)

The Act is costly to administer. Both the PCAOB and SEC are adding staff to cope with the additional work necessary to implement the Act. Rouse, (2005) points out that the PCAOB was established in January 2003 with a staff of eight. By the end of 2005 there were more than 450 staff members with a budget in excess of $\$ 150$ million. The SEC hired an additional 1,000 staff because of SOX.

The Act has had a negative effect on American industry. Successive studies by the Financial Executives International expound on this effect. The results of a January 2004 survey of 321 companies (FEI 2004a) indicated the Act cost an average of $\$ 1.3$ million in spending on external consulting and software, with additional audit fees of $\$ 1.5$ million (a jump of 35 percent)." By July 2004, FEI (2004b) another survey indicated the total cost of compliance was estimated to be $62 \%$ more than the January 2004 survey. A 2005 survey (FEI 2005) indicated a $39 \%$ increase from the July 2004 survey. In a 2007 survey (FEI 2007) those companies with market capitalizations more than \$75 million had an average cost of internal control compliance to be \$2.9 million during fiscal year 2006. This last survey runs counter to Rittenberg and Miller's (2005) contention that SOX costs may be leveling-off.

Other studies found similar issues - substantial increases in audit fees and negative effects on stock prices and the U.S. capital markets leading up to the passage of SOX (Griffin and Lont, 2004) (Ge and McVay, 2005), (Solomon and Bryan-Low, 2004), (Bargeron, Lehn, and Zutter, 2007) (Zhang, 2005).

Litvak (2007) attempted to examine the costs and benefits of SOX using a treatment group of non-US firms that are cross-listed on the US exchanges and matching those firms with other non-US firms to control for country, industry, and size. Litvak last event date was October 22, 2002 and found negative returns for the cross-listed firms. This study also compares a treatment group of firms subject to Sox with a control group not subject to SOX, but we use US firms in both groups and use a final date of 2005 to allow more time for the benefits of SOX to manifest themselves. We also examine reported profitability rather then stock prices because stock prices are not available for our control group. 


\section{Regulations and the Banking Industry}

Banking regulations appear to increase the cost of bank operations. According to the American Banking Association (ABA) and Federal Reserve, (Simmons, 2005), the cost of regulation in the banking industry ranges from $\$ 34$ billion to $\$ 42$ billion a year, not including the costs of the "Patriot Act, Sarbanes-Oxley, the GrammLeach-Bliley Act, additional promulgations of the Securities and Exchange Commission, Financial Accounting Standards Board, and Public Company Accounting Oversight Board." Other studies found that regulations add to bank and consumer costs, limit performance, while not increasing reporting information, (Benston and Kaufman, 1996), (Hagerman, 1975), (Bordo, Rockoff, and Redish, 1994) According to Jayaratne and Strahan (1998) it appears that SOX regulations may have many of those same idiosyncracies. Fernandez and Toto (2005) found that SOX increases bank costs and decreases bank CEO time availability to develop new business. Recently, Siegel et al. (2009) found evidence that the Sarbanes-Oxley Act may negatively impact U. S. banks.

In an attempt to relieve some of the cost pressures emanating from SOX, Thomas Venables, in testimony on behalf of the ABA (SEC 2007) before the Senate Committee on Small Business and Entrepreneurship, stated that because of the "increasing cost of being a registered public company, a number of small businesses, especially some of our member community banks, have determined that deregistration is in the best interests of their shareholders."

\section{RESEARCH DESIGN}

There are many studies indicating that SOX has added a substantial cost to U.S. business. However, many of the benefits of the Acts increased internal controls, such as better decision making and reduced potential for fraud, are difficult to quantify. American banks that fall under the mandates of the Securities and Exchange Commission (SEC) are required to implement SOX, hereafter referred to as "Registered Banks,". However, many American banks are privately owned and are not required to follow the requirements of the SEC and SOX hereafter referred to as "Nonregistered Banks,. By comparing the operating results of these two classes of banks during the period that the Act has been in place, a we may be able to evaluate the cost and benefits of SOX.

Research suggests that there is no innate operational efficiency based upon the manner in which a bank is owned: public or private. In their findings of the German banking industry Altunbas et al. (2001) found that inefficiency measures indicate that economies of scale have more influence over the efficient operation of banks than does the type of ownership.

In an attempt to isolate the impact of SOX we use an experimental design with the Nonregistered banks acting as the control group and the Registered banks as the treatment group. The year 2005 was selected as an attempt to reduce the impact of the 2008 financial crisis on the firms results. In 2005 the Registered banks will have implemented SOX, hence received the treatment, while the Nonregistered banks will not have been required to implement SOX and serve as a control group. This relationship is summarized in Table 1 below:

\begin{tabular}{|l|c|c|}
\hline \multicolumn{2}{|c|}{ Table 1: Research Design } \\
\begin{tabular}{|l|c|c|}
\hline Year & 2000 & 2005 \\
\hline Registered banks & Control & $\begin{array}{c}\text { Treatment - SOX } \\
\text { applied }\end{array}$ \\
\hline Nonregistered Banks & Control & $\begin{array}{c}\text { Control - SOX Not } \\
\text { required }\end{array}$ \\
\hline
\end{tabular} \\
\hline
\end{tabular}

There are many differences between the Registered and Nonregistered banks besides the implementation of SOX. To minimize the impact of these individual differences, we use data from the year 2000 which was selected 
because that is before SOX was implemented. Therefore, in 2000 neither the Registered banks nor Nonregistered banks will have been impacted by SOX. For each individual bank (i), we take the return on assets (ROA), and subtract the 2000 ROA for bank i from the 2005 ROA for bank i to yield a change in $\mathrm{ROA}_{\mathrm{i}}$ :

$\Delta \mathrm{ROA}_{\mathrm{i}}=\mathrm{ROA}_{\mathrm{i}, 2005}-\mathrm{ROA}_{\mathrm{i}, 2000}$

The same approach is used for Return on Equity (ROE):

$\Delta \mathrm{ROE}_{\mathrm{i}}=\mathrm{ROE}_{\mathrm{i}, 2005}-\mathrm{ROE}_{\mathrm{i}, 2000}$

By focusing on the change in returns for each individual bank, this should remove many of the unique factors impacting individual banks and help to isolate the treatment effect. If the costs and benefits of SOX are approximately equal then the mean $\triangle \mathrm{ROA}$ for the registered and nonregistered banks should be the same. If the benefits of SOX exceed the costs, then the mean $\triangle$ ROA of the Registered banks should be greater than the mean $\triangle \mathrm{ROA}$ of the Nonregistered banks. If the costs of SOX exceed the benefits then he mean $\triangle \mathrm{ROA}$ of the Registered banks should be less than the mean $\triangle \mathrm{ROA}$ of the Nonregistered banks:

$\mathbf{H}_{01}$ : The mean of the Registered banks $\triangle$ ROA is equal to the mean of the Nonregistered banks $\triangle R O A$.

$\mathbf{H}_{\mathrm{A} \mathbf{1}}$ : The mean of the Registered banks $\triangle \mathrm{ROA}$ is not equal to the mean of the Nonregistered banks $\Delta \mathrm{ROA}$.

We will also test the impact on ROE with the same expectations as ROA:

$\mathbf{H}_{02}$ : The mean of the Registered banks $\Delta \mathrm{ROE}$ is equal to the mean of the Nonregistered banks $\triangle \mathrm{ROE}$.

$\mathbf{H}_{\mathbf{A} 2}$ : The mean of the Registered banks $\Delta \mathrm{ROE}$ is not equal to the mean of the Nonregistered banks $\Delta \mathrm{ROE}$.

\section{DATA SELECTION AND DESCRIPTIVE STATISTICS}

In order to obtain the ROA and ROE data necessary for testing the above hypotheses U.S. bank financial data was collected from Federal Reserve archives for the years 2000 through 2005. The data included total assets, return on assets, return on equity and was segregated for "Registered" vs "Nonregistered" banks.

Exhibit 1 represents a summary of the mean and median of assets for Registered Banks and Nonregistered Banks. Although there are more Nonregistered Banks (878 to 1,525 vs 582 to 806 ) the Registered Banks are larger in terms of assets due to the fact that they have more shareholders and therefore a larger capital base.

\begin{tabular}{|c|c|c|c|c|}
\hline \multicolumn{5}{|c|}{$\begin{array}{c}\text { Mean and Median of Total Assets - Registered vs Nonregistered B } \\
\text { for the Years } 2000 \text { through } 2005 \\
\text { Exhibit 1 } \\
\text { (in thousands) }\end{array}$} \\
\hline \multicolumn{3}{|c|}{ Registered Banks } & \multicolumn{2}{|c|}{ Nonregistered Banks } \\
\hline Year & Mean & Median & Mean & Median \\
\hline 2000 & $\$ 10,084,592$ & $\$ 548,264$ & $\$ 1,251,692$ & $\$ 255,277$ \\
\hline 2001 & $\$ 10,683,614$ & $\$ 571,350$ & $\$ 1,354,701$ & $\$ 261,724$ \\
\hline 2002 & $\$ 10,678,611$ & $\$ 578,359$ & $\$ 1,259,431$ & $\$ 265,953$ \\
\hline 2003 & $\$ 11,289,990$ & $\$ 590,282$ & $\$ 1,272,544$ & $\$ 264,814$ \\
\hline 2004 & $\$ 13,481,377$ & $\$ 614,897$ & $\$ 1,936,212$ & $\$ 273,349$ \\
\hline 2005 & $\$ 15,833,654$ & $\$ 666,194$ & $\$ 2,110,894$ & $\$ 289,092$ \\
\hline
\end{tabular}




\section{DESCRIPTIVE STATISTICS AND HYPOTHESIS TESTS FOR CHANGE IN ROA AND ROE} in Exhibit 2.

Descriptive statistics for the $\triangle \mathrm{ROA}$ from 2000 to 2005 for Registered and Nonregistered banks are included

\begin{tabular}{|c|c|c|}
\hline & $\begin{array}{c}\text { Exhibit 2 } \\
\Delta \text { ROA from } 2000 \text { to } \\
2005\end{array}$ & \\
\hline & Registered Banks & Nonregistered Banks \\
\hline Number & 549 & 827 \\
\hline Mean & -0.03111 & 0.10655 \\
\hline Range & -5.45 to 3.48 & -4.92 to 7.38 \\
\hline Variance & 0.3114 & 0.4232 \\
\hline
\end{tabular}

As summarized in Exhibit 3, to test the difference in means, we use a two-tailed t-test with equal variances and found a probability of $5.10148 \mathrm{E}^{-5}$. Therefore we can reject the null hypothesis 1 and conclude that the costs of SOX exceed the benefits since the mean of the $\triangle \mathrm{ROA}$ is negative for the Registered Banks and positive for the Nonregistered banks.

\begin{tabular}{|c|c|c|}
\hline \multicolumn{3}{|c|}{ Exhibit 3} \\
\hline \multirow{3}{*}{\multicolumn{3}{|c|}{$\begin{array}{l}\text { Test results for } \mathrm{H}_{1} \text { : } \\
\text { t-Test: Two-Sample Assuming Equal Variances } \\
\text { Return on Assets }\end{array}$}} \\
\hline & & \\
\hline & & \\
\hline & Registered & Nonregistered \\
\hline Mean & -0.031111111 & 0.106553809 \\
\hline Variance & 0.311438362 & 0.423246584 \\
\hline Observations & 549 & 827 \\
\hline Pooled Variance & 0.378653494 & \\
\hline Hypothesized Mean Difference & 0 & \\
\hline df & 1374 & \\
\hline t Stat & -4.063797069 & \\
\hline $\mathrm{P}(\mathrm{T}<=\mathrm{t})$ one-tail & $2.55074 \mathrm{E}-05$ & \\
\hline t Critical one-tail & 1.645963382 & \\
\hline $\mathrm{P}(\mathrm{T}<=\mathrm{t})$ two-tail & $5.10148 \mathrm{E}-05$ & \\
\hline t Critical two-tail & 1.961691977 & \\
\hline
\end{tabular}

Descriptive statistics for the $\triangle \mathrm{ROE}$ from 2000 to 2005 for Registered and Nonregistered banks are included in Exhibit 4. 


\begin{tabular}{|l|c|c|}
\hline & $\begin{array}{c}\text { Exhibit 4 } \\
\begin{array}{c}|c| \\
\text { ROE from 2000 } \\
\text { to 2005 }\end{array}\end{array}$ \\
\hline & Registered Banks & $\begin{array}{c}\text { Nonregistered } \\
\text { Banks }\end{array}$ \\
\hline Number & 548 & 826 \\
\hline Mean & 0.858850365 & 0.666598063 \\
\hline Range & -121.16 to 41.96 & -59.07 to 60.23 \\
\hline Variance & 60.834 & 54.047 \\
\hline
\end{tabular}

Exhibit 5 summarizes the results of the test of the difference in means for Return on Equity (ROE). We use a two-tailed t-test with equal variances and found a probability of 0.000246763 . Therefore we can reject the null hypothesis 2 and conclude that the costs of SOX exceed the benefits since the mean of the $\triangle \mathrm{ROE}$ is negative for the Registered Banks and positive for the Nonregistered banks.

\begin{tabular}{|c|c|c|}
\hline \multicolumn{3}{|c|}{$\begin{array}{l}\text { Exhibit } 5 \\
\text { Test results for } \mathrm{H}_{1} \text { : } \\
\text { t-Test: Two-Sample Assuming Equal Variances }\end{array}$} \\
\hline & Registered & Nonregistered \\
\hline Mean & -0.858850365 & 0.666598063 \\
\hline Variance & 60.83485188 & 54.04736332 \\
\hline Observations & 548 & 826 \\
\hline Pooled Variance & 56.75345387 & \\
\hline Hypothesized Mean Difference & 0 & \\
\hline df & 1372 & \\
\hline t Stat & -3.675262115 & \\
\hline $\mathrm{P}(\mathrm{T}<=\mathrm{t})$ one-tail & 0.000123381 & \\
\hline t Critical one-tail & 1.645965001 & \\
\hline $\mathrm{P}(\mathrm{T}<=\mathrm{t})$ two-tail & 0.000246763 & \\
\hline t Critical two-tail & 1.961694498 & \\
\hline
\end{tabular}

\section{SUMMARY AND CONCLUSIONS}

This analysis found that since the means of the $\triangle \mathrm{ROA}$ and $\triangle \mathrm{ROE}$ are negative for the Registered Banks and positive for the Nonregistered banks This finding together with the Altunbas et al. (2001) study indicating that economies of scale have more influence over the efficient operations of banks than do the types of bank ownership: public (i.e. SEC reporting) vs private may indicate that for Registered banks, the costs of SOX exceed the benefits.

There are recommendations being made by the banking industry to the SEC. The American Banking Association (SEC 2007) recommends updating the Exchange Act registration shareholder threshold to between 1500 and 3000 record shareholders and change the threshold for deregistration to be 900 to 1800 record shareholders. Currently according to Section 12(g) of the Securities Exchange Act of 1934 (SEC 2004b) any issuer engaged in 
interstate commerce or whose securities are traded by use of the mails or any means of interstate commerce and has assets exceeding $\$ 1,000,000$ and equity securities held by five hundred or more must file a registration statement with the SEC, thus making the company subject to SOX. To obtain an exemption (SEC 2007) to the Section 12(g) requirements as per Rule $12 \mathrm{~h}-3(\mathrm{~b})(1)$, the SEC can allow a companies to deregister if they have less than $\$ 10$ million in assets or less than 300 shareholders.

For its part, the SEC appears receptive to constructive recommendations regarding SOX. According to Nicolaisen, Chief Accountant for the Securities and Exchange Commission in a speech at the 11th Annual Midwestern Financial Reporting Symposium in 2004 (SEC 2004a) stated that "the burden [of SOX] to smaller companies may be disproportionately higher and needs to be appropriately weighed as we determine the best ways to protect investors. This balancing act is something that I will continue to monitor closely, and it is also an important consideration for the PCAOB and for the FASB. Clearly we all need to strike the right balance...I can assure you that where changes in our rules are needed, I will support such change."

In any event Sarbanes-Oxley appears to have presented a challenge to American business. Because the Act is relatively new, research has been limited; thus, conclusions drawn by this paper have a major limitation concerning the effect of Sarbanes-Oxley on the banking industry.

\section{AUTHOR INFORMATION}

Philip H. Siegel, Currently the Peter S. Knox, III distinguished chair of accounting at Augusta State University. He secured his Ph.D. in accounting from the University of Memphis and is a CPA (state of Florida). His research has appeared in Journal of Business Ethics; Journal of Accounting, Auditing, \& Finance; Journal of Applied Business Research; Journal of the American Taxation Association; and other peer-reviewed journals.

David P. Franz, CMA and professor of accounting, has been teaching at San Francisco State University since 1987. He earned his Ph.D. from Penn State University. He has published and presented numerous articles on four continents in journals such as Journal of Business, Finance, and Accounting; Small Business Controller; and Indian Journal of Accounting.

John O'shaughnessy, Currently a Professor of Accounting at San Francisco State University. He is a Ph.D., CPA (inactive), CIA and CMA. His research interests include accounting ethics, auditing and internal controls. His research has been published in Internal Auditing; Managerial Auditing Journal; Journal of Business Ethics; and the CPA Journal.

\section{REFERENCES}

1. Admati, Anat R. and Paul Pfleiderer, "Forcing Firms to Talk: Financial Disclosure Regulation and Externalities," The Review of Financial Studies, Vol. 13, No. 3. (Autumn, 2000), pp. 479-519.

2. Altunbas, Yener, Lynne Evans, Philip Molyneux, "Bank Ownership and Efficiency," Journal of Money, Credit and Banking, Vol. 33, No. 4 (Nov., 2001), pp. 926-954

3. Apostolou, Barbara; William R. Pasewark and Jerry R. Strawser, "The Effects of Senior Internal Auditor Behaviour on Staff Performance and Satisfaction," Accounting and Business Research, Vol. 23. No. 90. pp. 110-122. 1993

4. Baird, Byron N. and Alfred R. Michenzi, "The Impact of the Foreign Corrupt Practices Act," The Internal Auditor, June 1983, pp. 20-22.

5. Bargeron, Leonce, Kenneth Lehn, and Chad Zutter, " Sarbanes-Oxley and Corporate Risk-Taking," presented at the University of Pittsburgh American Enterprise Institute, June 18, 2007, available at www.aei.org/docLib/20070615_LehnSOX.pdf

6. $\quad$ Beck, Paul J.; Michael W. Maher; and Adrian E. Tschoegl, "The Impact of the Foreign Corrupt Practices Act on US Exports," Managerial and Decision Economics, Vol. 12, No. 4. (Aug., 1991), pp. 295-303.

7. Benston, George J. "Public (U.S.) Compared to Private (U.K.) Regulation of Corporate Financial Disclosure," The Accounting Review, Vol. 51, No. 3. (Jul., 1976), pp. 483-498. 
8. Benston, George J. "An Appraisal of the Costs and Benefits of Government-Required Disclosure: SEC and FTC Requirements," Law and Contemporary Problems, Vol. 41, No. 3, Reweaving the Corporate Veil. (Summer, 1977), pp. 30-62.

9. Benston, George J. and George G. Kaufman, "The Appropriate Role of Bank Regulation," The Economic Journal, Vol. 106, No. 436. (May, 1996), pp. 688-697.

10. Boardman, Anthony E. and Aidan R. Vining, "Ownership and Performance in Competitive Environments: A Comparison of the Performance of Private, Mixed, and State-Owned Enterprises," Journal of Law and Economics, Vol. 32, No. 1. (Apr., 1989), pp. 1-33.

11. Bordo, Michael D.; Hugh Rockoff and Angela Redish, "The U.S. Banking System From a Northern Exposure: Stability versus Efficiency," The Journal of Economic History, Vol. 54, No. 2, (June, 1994), pp. 325-341.

12. CA Magazine, “AICPA report first to assess internal controls,” Mar1994, Vol. 127 Issue 2, p. 12.

13. Caves, Douglas W.; Laurits R. Christensen; Joseph A. Swanson, "Economic Performance in Regulated and Unregulated Environments: A Comparison of U.S. and Canadian Railroads," The Quarterly Journal of Economics, Vol. 96, No. 4. (Nov., 1981), pp. 559-581.

14. Chang, Ha-Joon, "The Economics and Politics of Regulation," Cambridge Journal of Economics Vol. 21, (1997), pp. 703-728

15. Committee of Sponsoring Organizations, "Report of the National Commission on Fraudulent Financial Reporting," October 1987 Available at http://www.coso.org/Publications/NCFFR.pdf

16. Copley, Paul A.; Mary S. Doucet; Kenneth M. Gaver, “A Simultaneous Equations Analysis of Quality Control Review Outcomes and Engagement Fees for Audits of Recipients of Federal Financial Assistance," The Accounting Review, Vol. 69, No. 1. (Jan., 1994), pp. 244-256.

17. Dhaliwal, Dan S. "Disclosure Regulations and the Cost of Capital," Southern Economic Journal, Vol. 45, No. 3. (Jan., 1979), pp. 785-794.

18. Felix, William L., Jr.; Audrey A. Gramling; and Mario J. Maletta, "The Contribution of Internal Audit as a Determinant of External Audit Fees and Factors Influencing This Contribution," Journal of Accounting Research, Vol. 39, No. 3. (Dec., 2001), pp. 513-534.

19. Fernandez, Frank A. and Grace Toto, "The Costs of Compliance in the U.S. Securities Industry," Securities Industry Association Research Reports, Volume VI, No. 8 August 31, 2005

20. Financial Executives International (FEI), "FEI Survey: Management Drives Sarbanes-Oxley Compliance Costs Down, But Auditor Fees Virtually Unchanged," Financial Executives International Press Release, May 16, 2007. Available at http://fei.mediaroom.com/index.php?s=press_releases\&item=187. Financial Executives International (FEI), "Sarbanes-Oxley Compliance Costs Exceed Estimates Companies Say Section 404 Improves Investor Confidence, But Question Cost vs. Benefit; Suggest Improvements," Financial Executives International Press Release , March 21, 2005. Available at http://www2.financialexecutives.org/files/spacer.cfm?file_id=1498.

21. Financial Executives International (FEI), "Sarbanes-Oxley Compliance Cost Estimates Soar 62\% Since January '04," Financial Executives International Press Release, August 11, 2004(b). Available at http://www2.financialexecutives.org/files/spacer.cfm?file_id=1151.

22. Financial Executives International (FEI), "Size Matters: Larger Companies Will Spend More for SarbanesOxley Compliance Requirements - Section 404 Could Cost Big Companies \$4.6 Million, Or More,” Financial Executives International Press Release , February 10, 2004(a). Available at http://www2.financialexecutives.org/files/spacer.cfm?file id=788.

23. Gagne, Margaret L., Joanne H. Gavin, and Gregory J. Tully, "Assessing the Costs and Benefits of Ethics: Exploring a Framework,” Business and Society Review, Vol. 110 No. 2, (2005) pp. 181-190.

24. Ge, Weili, and Sarah McVay, "The Disclosure of Material Weaknesses in Internal Controls after the Sarbanes-Oxley Act,” Accounting Horizons Vol. 19 No. 3 September 2005, pp. 137-158.

25. Gibbins, Michael; Alan Richardson; and John Waterhouse, "The Management of Corporate Financial Disclosure: Opportunism, Ritualism, Policies, and Processes

26. Journal of Accounting Research, Vol. 28, No. 1. (Spring, 1990), pp. 121-143.

27. Graham, John L., "The Foreign Corrupt Practices Act: A New Perspective," Journal of International Business Studies, Vol. 15, No. 3. (Winter, 1984), pp. 107-121.

28. Gray, Wayne B. "The Cost of Regulation: OSHA, EPA and the Productivity Slowdown," The American Economic Review, Vol. 77, No. 5. (Dec., 1987), pp. 998-1006. 
29. Griffin, Paul A. and David H. Lont, "An Analysis of Audit Fees Following the Passage of SarbanesOxley,” Working Paper Series, Social Science Research Network, December 13, 2004. Available at http://papers.ssrn.com/sol3/papers.cfm?abstract_id=649367

30. Hagerman, Robert L., "A Test of Government Regulation of Accounting Principles," The Accounting Review, Vol. 50, No. 4. (Oct., 1975), pp. 699-709.

31. Hahn, Robert W., "Policy Watch: Government Analysis of the Benefits and Costs of Regulation," The Journal of Economic Perspectives, Vol. 12, No. 4. (Autumn, 1998), pp. 201-210.

32. Harvard Law Review, "The Good, the Bad, and Their Corporate Codes of Ethics: Enron, Sarbanes-Oxley, and the Problems with Legislating Good Behavior," Vol. 116, No. 7. (May, 2003), pp. 2123-2141.

33. Heldack, John M., "A Study of Questionable Foreign Payments by American Multinational Corporations," $\mathrm{PhD}$ dissertation, Golden Gate University, 1977.

34. Jayaratne, Jith and Philip E. Strahan, "Entry Restrictions, Industry Evolution, and Dynamic Efficiency: Evidence from Commercial Banking," Journal of Law and Economics, Vol. 41, No. 1. (Apr., 1998), pp. 239-273.

35. Kaikati, Jack G. and Wayne A. Label, "American Bribery Legislation: An Obstacle to International Marketing," Journal of Marketing, Vol. 44, No. 4. (Autumn, 1980), pp. 38-43.

36. Koretz, Gene, "Bribes Can Cost the U.S. an Edge," Business Week; 4/15/96 Issue 3471, p30-30,

37. Leuz, Christian and Robert E. Verrecchia, "The Economic Consequences of Increased Disclosure,” Journal of Accounting Research, Vol. 38, Supplement: Studies on Accounting Information and the Economics of the Firm. (2000), pp. 91-124.

38. Litvak, Kate, "The effect of the Sarbanes-Oxley act on non-US companies cross-listed in the US," Journal of Corporate Finance, Vol. 13 (2007) pp. 195-228.

39. Maher, Michael W. "The Impact of Regulation on Controls: Firms' Response to the Foreign Corrupt Practices Act," The Accounting Review, Vol. 56, No. 4. (Oct., 1981), pp. 751-770.

40. Matsumura, Ella Mae and Robert R. Tucker, "Fraud Detection: A Theoretical Foundation," The Accounting Review, Vol. 67, No. 4. (Oct., 1992), pp. 753-782.

41. Meier-Schatz, Christian J., "Disclosure Rules in the U. S., Germany and Switzerland," The American Journal of Comparative Law, Vol. 34, No. 2. (Spring, 1986), pp. 271-294.

42. Meyer, Robert A., "Publicly Owned versus Privately Owned Utilities: A Policy Choice," The Review of Economics and Statistics, Vol. 57, No. 4. (Nov., 1975), pp. 391-399.

43. Niskanen, William A., "U.S. Capital Markets May Be Dangerously Overregulated," World Commerce Review, August 28, 2007. Available at https://www.cato.org/pub_display.php?pub_id=8675

44. Perl, Lewis and Frederick C. Dunbar, "Cost Effectiveness and Cost-Benefit Analysis of Air Quality Regulations," The American Economic Review, Vol. 72, No. 2, Papers and Proceedings of the NinetyFourth Annual Meeting of the American Economic Association. (May, 1982), pp. 208-213.

45. H. Craig Petersen, “An Empirical Test of Regulatory Effects,” The Bell Journal of Economics, Vol. 6, No. 1 (Spring, 1975), pp. 111-126.

46. Pociask, Stephen B. and Joseph P. Fuhr, Jr., Larry F. Darby, "Insurance Regulation: Market or Government Failure?" The American Consumer Institute, March 20, 2007

47. Richman, B. “Can We Prevent Questionable Foreign Payments?” Business Horizons, June 1979, pp. 14-19.

48. Rittenberg, Larry E. and Patricia K. Miller, "Sarbanes-Oxley Section 404 Work Looking at the Benefits," The Institute of Internal Auditors Research Foundation, Altamonte Springs, Florida, January 2005.

49. Rouse, Robert W., "Companies grapple with uneasiness, confusion, and restatement," The Journal of Corporate Accounting \& Finance; Mar/Apr 2005; 16, 3; pg. 93

50. Satish Joshi; Ranjani Krishnan; Lester Lave, "Estimating the Hidden Costs of Environmental Regulation," The Accounting Review, Vol. 76, No. 2. (Apr., 2001), pp. 171-198.

51. Schneider, Arnold and Neil Wilner, "A Test of Audit Deterrent to Financial Reporting Irregularities Using the Randomized Response Technique," The Accounting Review, Vol. 65, No. 3. (Jul., 1990), pp. 668-681.

52. Securities and Exchange Commission (SEC). 2002. Public Law 107-204_July 30, 2002 (The SarbanesOxley Act) Washington, D.C., July 30, 2002. Available at http://www.sec.gov/about/laws/soa2002.pdf

53. Securities and Exchange Commission (SEC). 2003. SEC Implements Internal Control Provisions of Sarbanes-Oxley Act; Adopts Investment Company R\&D Safe Harbor Washington, D.C., May 27, 2003. Available at http://www.sec.gov/news/press/2003-66.htm 
54. Securities and Exchange Commission (SEC) 2004a. "Speech by SEC Staff: Keynote Speech at 11th Annual Midwestern Financial Reporting Symposium by Donald T. Nicolaisen - Chief Accountant of the U.S. Securities and Exchange Commission," October 7, 2004. Available at http://www.sec.gov/news/speech/spch100704dtn.htm

55. Securities and Exchange Commission (SEC). 2004a. "The Securities Exchange Act of 1934 (revised through September 30, 2004)." September 30, 2004. Available at http://www.sec.gov/about/laws/sea34.pdf

56. Securities and Exchange Commission (SEC). 2004b. "The Securities Exchange Act of 1934 (revised through September 30, 2004)." September 30, 2004. Available at http://www.sec.gov/about/laws/sea34.pdf

57. Securities and Exchange Commission (SEC). 2005. Re: Implementation of U.S. Sarbanes-Oxley Act Internal Control Provisions - File Number 4-497 - Response," March 31, 2005. Available at http://www.sec.gov/news/press/4-97/darichards033105.pdf

58. Securities and Exchange Commission (SEC). 2007. "Testimony Of Thomas Venables," On Behalf of the American Bankers Association Before the Committee on Small Business and Entrepreneurship United States Senate April 18, 2007. Available at http://www.aba.com/NR/rdonlyres/3C261ABA-BDCE-437AA451-79F8AF42F5A4/46662/ABAApril182007Hearing.pdf

59. Siegel, Philip H., John O’Shaughnessy, and David P. Franz, "The Sarbanes-Oxley Act and U.S. Banking Industry," Bank Accounting \& Finance, Vol. 23 (April-May 2009) p 25-27.

60. Simmons, Harris H. "Regulation: How much does it cost you?" ABA Banking Journal, Vol. 14, (December 2005) p. 14.

61. Solomon, Deborah and Cassell Bryan-Low, "Companies Complain About Cost Of Corporate-Governance Rules," The Wall Street Journal, February 10, 2004.

62. Spann, Robert M., "Rate of Return Regulation and Efficiency in Production: An Empirical Test of the Averch-Johnson Thesis," The Bell Journal of Economics and Management Science, Vol. 5, No. 1. (Spring, 1974), pp. 38-52.

63. Sunstein, Cass R. "Informational Regulation and Informational Standing: Akins and beyond," University of Pennsylvania Law Review, Vol. 147, No. 3. (Jan., 1999), pp. 613-675.

64. Swartz, Nikki, "Small Firms Seek Different SOX Rules," Information Management Journal, Jan/Feb2006, Vol. 40 Issue 1, p6-7

65. Zhang, Ivy Xiying, "Economic Consequences of the Sarbanes-Oxley Act of 2002," Journal of Accounting and Economics, Vol. 44, Issues 1-2, September 2007, Pages 74-115 
NOTES 